\title{
Chlorophyll index for real-time prediction of nutritional status of 'Prata' banana
}

\author{
Alessandro de M. Arantes ${ }^{1}$, Sérgio L. R. Donato ${ }^{1}$, Dalmo L. de Siqueira ${ }^{2}$, \\ Edson P. Amorim ${ }^{3} \&$ Vagner A. Rodrigues Filho ${ }^{1}$ \\ ${ }^{1}$ Instituto Federal Baiano. Guanambi, BA. E-mail: alessandro.arantes@guanambi.ifbaiano.edu.br (Corresponding author); sergio.donato@guanambi.ifbaiano.edu.br; \\ vagner_loiola@yahoo.com.br \\ ${ }^{2}$ Universidade Federal de Viçosa/Departamento de Fitotecnia. Viçosa, MG. E-mail: siqueira@mail.ufv.br \\ ${ }^{3}$ EMBRAPA-CNPMF. Cruz das Almas, BA. E-mail: edson.amorim@embrapa.br
}

Key words:

Musa spp.

cultivars

nutrients

chlorophyll

\begin{abstract}
A B S T R A C T
This study aimed to select regression equations based on the correlation between chlorophyll index and leaf nutrient contents, for real-time prediction of the nutritional status of 'Prata' banana. Six cultivars of 'Prata' banana were used as treatments, with five replicates and four plants per plot, arranged in a completely randomized design. Nutrient levels were evaluated based on laboratorial analysis and chlorophyll indices using a portable chlorophyll meter, in the third leaf from the apex to the base. Data were subjected to analysis of variance, calculating the correlations between leaf nutrient contents and chlorophyll indices, and the regression equations were adjusted to the associations that were significant and with greater magnitude. The selected models estimate leaf nutrient contents and allow a real-time, low-cost reliable prediction of the nutritional status of 'Prata' banana. It is an auxiliary technique that, combined with leaf and soil analysis, contributes to a more precise and secure nutritional evaluation.
\end{abstract}

\section{Índice de clorofila para predição do estado nutricional de bananeiras tipo Prata em tempo real}

\begin{abstract}
R E S U M O
Objetivou-se, com o presente trabalho, selecionar equações de regressão com base na correlação entre o índice de clorofila e os teores foliares de nutrientes para predição em tempo real do estado nutricional de bananeiras tipo Prata. Utilizaram-se, como tratamentos, seis cultivares de bananeira tipo Prata com cinco repetições e quatro plantas úteis por parcela, dispostas em delineamento experimental inteiramente casualizado. Avaliaram-se os teores de nutrientes com base em análises laboratoriais e os índices de clorofila com um medidor portátil na terceira folha do ápice para a base. Os dados foram submetidos à análise de variância; calcularam-se as correlações entre teores foliares de nutrientes e índices de clorofila e se ajustaram equações de regressões para as associações significativas e com maior magnitude. Os modelos selecionados estimam os teores foliares de nutrientes e permitem predizer com segurança em tempo real e a baixo custo, o estado nutricional de bananeiras tipo Prata. Constitui uma técnica auxiliar que, aliada à diagnose foliar e à análise de solos, contribui para uma avaliação nutricional mais criteriosa e segura.
\end{abstract}




\section{INTRODUCTION}

Banana plants are highly demanding in nutrients, especially potassium and nitrogen, which makes fertilization the most costly production factor and the one that influences the amount and quality of the production, as the resistance to diseases.

Nutritional evaluation is essential for the recommendation of fertilization for the crop. Leaf tissue analysis, combined with soil chemical analysis and visual diagnosis, reflects the dynamics of nutrients in the soil-plant system (Donato et al., 2010).

The joint use of these techniques allows increasing the precision of the diagnosis, but the reliability of the results depends on the sampling process and the technical knowledge of the evaluator. The costs and the delay in obtaining the results hamper the decision-making process, which may represent losses in production and quality.

The use of indirect measurements to determine the demand for nutrients has been studied, especially due to its speed, easy determination and low cost. Real-time information supporting the evaluation of nutritional status of banana is essential for the decision-making process in production systems that have increasingly demanded production precision and security (Fontes, 2011).

The existence of correlation between chlorophyll leaf contents determined in the laboratory through spectrophotometer or indirect chlorophyll meters and plant growth characteristics, as well as leaf nutrient contents, especially $\mathrm{N}$, has been shown in experiments with different crops (Reis et al., 2006; Godoy et al., 2008; Ribeiro et al., 2009; Backes et al., 2010; Pôrto et al., 2011; Haim et al., 2012).

However, studies of this nature are lacking for the banana crop (Melo et al., 2014). Chlorophyll content can be estimated from its correlation with a dimensionless value generated by the chlorophyll meter, which measures the green color intensity, based on values calculated by the differential reading of the amount of light transmitted by the leaf in two wavelength regions: $650 \mathrm{~nm}$, at which light is absorbed by chlorophyll and $940 \mathrm{~nm}$, at which light is not absorbed (Swiader \& Moore, 2002).

The correlation between the chlorophyll index and the leaf contents of nutrients allows the adjustment of models to predict the nutritional status of the banana crop. In addition, it is easily measured and non-destructive.

This study aimed to adjust regression equations based on the correlation between the chlorophyll index, estimated using a chlorophyll meter, and leaf nutrient contents determined in the laboratory, to provide a real-time prediction of the nutritional status of 'Prata' banana.

\section{Material AND Methods}

The experiment was carried out from 2010 to 2012 in a Red Yellow Latosol at the Federal Institute of Bahia, Campus of Guanambi, with mean annual rainfall and temperature of $680 \mathrm{~mm}$ and $26^{\circ} \mathrm{C}$, respectively.

Samples of the soil used for the installation of the banana orchard, from the layers of $0-20 \mathrm{~cm}$ and $21-40 \mathrm{~cm}$, were sent to the Laboratory of Soils of the Northern Minas Gerais Regional
Unit of EPAMIG (Agricultural Research Company of Minas Gerais) and their chemical properties are shown in Table 1.

Soil samples from the layer of $0-20 \mathrm{~cm}$ were collected at the end of the second production cycle in all the plots and the contents of nutrients are shown in Table 2.

Micropropagated seedlings were planted (May 11, 2010) at the spacing of $3.0 \times 2.5 \mathrm{~m}$, totaling 1,333 plants per hectare. Implantation and cultural practices followed the recommendations for the crop (Rodrigues et al., 2008).

At planting and every two months, during both production cycles, organic fertilizations were performed using $36 \mathrm{~L}$ of cattle manure, which correspond to $13.68 \mathrm{~kg}$ per cluster of plants, with the following composition: organic matter content $=$ $63.73 \mathrm{~g} \mathrm{~kg}^{-1}$; moisture at $65^{\circ} \mathrm{C}=16.72 \% ; \mathrm{pH}=7.42$; density $=$ $0.38 \mathrm{~g} \mathrm{~cm}^{-3}$; macronutrients $(\mathrm{N}, \mathrm{P}, \mathrm{K}, \mathrm{Ca}, \mathrm{Mg}$ and $\mathrm{S})=5.2,4.7$, $2.5,1.7,0.2$ and $2.3 \mathrm{~g} \mathrm{~kg}^{-1}$, respectively and micronutrients (B, $\mathrm{Cu}, \mathrm{Zn}, \mathrm{Mn}$ and $\mathrm{Fe})=2.1,45.2,200.5,391.8$ and 1,932.4 mg $\mathrm{kg}^{-1}$, respectively.

Four months after planting and during the flowering of each cycle, $25 \mathrm{~g}$ of $\mathrm{Mg}$ and $30 \mathrm{~g}$ of $\mathrm{K}_{2} \mathrm{O}$ per cluster of plants were applied broadcast, using magnesium sulfate and potassium chloride. Applications of B and $\mathrm{Zn}$ were performed in the rhizome (Rodrigues et al., 2007; Nomura et al., 2011) of the thinned seedling, every four months, with $1.7 \mathrm{~g}$ of $\mathrm{B}$, as boric acid, and $4 \mathrm{~g}$ of $\mathrm{Zn}$ per cluster of plants, as zinc sulfate.

Sprinkler irrigation was performed using Netafim ${ }^{\star}$ pressure-compensating emitters, with flow rate of $120 \mathrm{~L} \mathrm{~h}^{-1}$, radius of throw of $7.4 \mathrm{~m}$, a red nozzle of $1.57 \mathrm{~mm}$, spaced by 6 $\mathrm{m}$ between lateral lines and $5 \mathrm{~m}$ between emitters.

The water used in the experiment came from a tubular well and is classified as C3S1 - water with high salinity and low sodium concentration, with the following chemical characteristics: $\mathrm{pH}=6.6$, Electrical conductivity $=0.82 \mathrm{dS} \mathrm{m}^{-1}$

Table 1. Chemical characteristics of two composite soil samples, from the layers of 0-20 and $21-40 \mathrm{~cm}$, collected in the experimental area

\begin{tabular}{|c|c|c|c|c|c|}
\hline Char. & Unit & $\begin{array}{l}0-20 \\
\mathrm{~cm}\end{array}$ & $\begin{array}{l}\text { Standard } \\
\text { deviation }\end{array}$ & $\begin{array}{c}21-40 \\
\mathrm{~cm}\end{array}$ & $\begin{array}{l}\text { Standard } \\
\text { deviation }\end{array}$ \\
\hline $\mathrm{pH}\left(\mathrm{H}_{2} \mathrm{O}\right)$ & & 7.60 & 0.14 & 7.60 & 0.57 \\
\hline$P$ & $\mathrm{mg} \mathrm{dm} \mathrm{dm}^{-3}$ & 318.15 & 157.47 & 185.80 & 21.78 \\
\hline K & $\mathrm{mg} \mathrm{dm}^{-3}$ & 567.50 & 45.96 & 512.50 & 154.86 \\
\hline $\mathrm{Na}^{+}$ & $\mathrm{cmol}_{\mathrm{c}} \mathrm{dm}^{-3}$ & 0.20 & 0.00 & 0.15 & 0.07 \\
\hline $\mathrm{Ca}^{2+}$ & $\mathrm{cmol}_{\mathrm{c}} \mathrm{dm}^{-3}$ & 3.45 & 0.49 & 2.90 & 0.00 \\
\hline $\mathrm{Mg}^{2+}$ & $\mathrm{cmol}_{\mathrm{c}} \mathrm{dm}^{-3}$ & 1.70 & 0.28 & 1.30 & 0.00 \\
\hline $\mathrm{Al}^{3+}$ & $\mathrm{cmol}_{\mathrm{c}} \mathrm{dm}^{-3}$ & 0.00 & 0.00 & 0.00 & 0.00 \\
\hline $\mathrm{H}^{+}+\mathrm{Al}^{3+}$ & $\mathrm{cmol}_{\mathrm{c}} \mathrm{dm}^{-3}$ & 0.90 & 0.00 & 0.95 & 0.07 \\
\hline S.B. ${ }^{1}$ & $\mathrm{cmol}_{\mathrm{c}} \mathrm{dm}^{-3}$ & 6.75 & 0.92 & 5.65 & 0.35 \\
\hline$t^{2}$ & $\mathrm{cmol}_{\mathrm{c}} \mathrm{dm}^{-3}$ & 6.75 & 0.92 & 5.65 & 0.35 \\
\hline $\mathrm{T}^{3}$ & $\mathrm{cmol}_{\mathrm{C}} \mathrm{dm}^{-3}$ & 7.65 & 0.92 & 6.65 & 0.21 \\
\hline$V^{4}$ & $\%$ & 88.00 & 1.41 & 85.00 & 1.41 \\
\hline $\mathrm{m}^{5}$ & $\%$ & 0.00 & 0.00 & 0.00 & 0.00 \\
\hline $0 . \mathrm{M}^{6}{ }^{6}$ & $\mathrm{dag} \mathrm{dm}^{-3}$ & 1.35 & 0.21 & 1.00 & 0.14 \\
\hline B & $\mathrm{mg} \mathrm{dm}{ }^{-3}$ & 0.85 & 0.07 & 0.75 & 0.07 \\
\hline $\mathrm{Cu}^{++}$ & $\mathrm{mg} \mathrm{dm} \mathrm{dm}^{-3}$ & 1.05 & 0.21 & 0.85 & 0.21 \\
\hline $\mathrm{Fe}^{++}$ & $\mathrm{mg} \mathrm{dm}^{-3}$ & 11.85 & 2.33 & 11.35 & 3.46 \\
\hline $\mathrm{Mn}^{++}$ & $\mathrm{mg} \mathrm{dm}{ }^{-3}$ & 48.95 & 3.75 & 40.70 & 11.60 \\
\hline $\mathrm{Zn}^{++}$ & $\mathrm{mg} \mathrm{dm}^{-3}$ & 24.25 & 4.31 & 13.30 & 2.40 \\
\hline P-rem 7 & $\mathrm{Mg} \mathrm{L}^{-1}$ & 42.15 & 0.92 & 41.40 & 3.68 \\
\hline $\mathrm{EC}^{8}$ & $\mathrm{dS} \mathrm{m}^{-1}$ & 1.70 & 0.00 & 1.95 & 0.21 \\
\hline
\end{tabular}

Char. - Characteristics; ${ }^{1}$ Sum of bases; ${ }^{2}$ Effective cation exchange capacity (effective CEC); ${ }^{3} \mathrm{CEC}$ at $\mathrm{pH}$ 7.0; ${ }^{4}$ Base saturation; ${ }^{5}$ Aluminum saturation; ${ }^{6}$ Organic matter; ${ }^{7}$ Remaining phosphorus; ${ }^{8}$ Electrical conductivity; $\mathrm{pH}$ in water; $\mathrm{OM}$ - Colorimetry; $\mathrm{P}, \mathrm{K}, \mathrm{Na}, \mathrm{Cu}, \mathrm{Fe}, \mathrm{Mn}$ and $\mathrm{Zn}$ - Mehlich-1 Extractor; $\mathrm{Ca}, \mathrm{Mg}$ and $\mathrm{Al}-1$ mol L-1 KCI Extractor; $\mathrm{H}+\mathrm{Al}$ : pH SMP; $\mathrm{B}$ - Hot water 
Table 2. Mean values of soil chemical characteristics in the layer of $0-20 \mathrm{~cm}$, in area cultivated with different 'Prata' banana cultivars, after two production cycles

\begin{tabular}{|c|c|c|c|c|c|c|c|c|c|}
\hline Characteristics & Unit & Maravilha & BRS FHIA- 18 & FHIA-18 & BRS Platina & Prata-Anã & JV42-135 & Mean & CV (\%) \\
\hline $\mathrm{pH}^{1}$ & - & 7.53 & 7.59 & 7.44 & 7.47 & 7.59 & 7.63 & 7.54 & 2.16 \\
\hline $\mathrm{OM}^{2}$ & dag $\mathrm{kg}^{-1}$ & 2.33 & 1.69 & 2.13 & 1.89 & 2.03 & 2.34 & 2.07 & 30 \\
\hline$P^{3}$ & $\mathrm{mg} \mathrm{dm}^{3}$ & 412.21 & 342.67 & 388.74 & 343.73 & 362.89 & 399.3 & 374.92 & 20.16 \\
\hline $\mathrm{K}^{3}$ & $\mathrm{mg} \mathrm{dm}-^{3}$ & 278.71 & 313.71 & 326.43 & 272.86 & 283.14 & 308.14 & 297.17 & 51.48 \\
\hline $\mathrm{Na}^{3}$ & $\mathrm{cmol}_{\mathrm{c}} \mathrm{dm}^{-3}$ & 0.23 & 0.26 & 0.24 & 0.26 & 0.26 & 0.24 & 0.25 & 35.62 \\
\hline $\mathrm{Ca}^{4}$ & $\mathrm{cmol}_{\mathrm{c}} \mathrm{dm}^{-3}$ & 4.96 & 4.43 & 4.79 & 4.59 & 4.89 & 5.04 & 4.78 & 12.69 \\
\hline $\mathrm{Mg}^{4}$ & $\mathrm{cmol}_{\mathrm{c}} \mathrm{dm}^{-3}$ & 2.76 & 2.56 & 2.87 & 2.76 & 2.93 & 2.96 & 2.81 & 20.99 \\
\hline $\mathrm{H}+\mathrm{Al}^{5}$ & $\mathrm{cmol}_{\mathrm{c}} \mathrm{dm}^{-3}$ & 0.79 & 0.81 & 0.79 & 0.8 & 0.74 & 0.79 & 0.79 & 12.93 \\
\hline SB & $\mathrm{cmol}_{\mathrm{c}} \mathrm{dm}^{-3}$ & 8.69 & 8.04 & 8.73 & 8.29 & 8.79 & 9.01 & 8.59 & 10.44 \\
\hline $\mathrm{t}$ & $\mathrm{cmol}_{\mathrm{c}} \mathrm{dm}^{-3}$ & 8.69 & 8.04 & 8.73 & 8.29 & 8.79 & 9.01 & 8.59 & 10.44 \\
\hline $\mathrm{T}$ & $\mathrm{cmol}_{\mathrm{c}} \mathrm{dm}^{-3}$ & 9.46 & 8.86 & 9.5 & 9.1 & 9.49 & 9.77 & 9.36 & 9.15 \\
\hline V & $\%$ & 91.57 & 91 & 91.57 & 91 & 92.14 & 91.71 & 91.5 & 1.65 \\
\hline$B^{6}$ & $\mathrm{mg} \mathrm{dm}^{-3}$ & 5.26 & 0.97 & 1.1 & 1.23 & 1.29 & 1.01 & 1.81 & 254.47 \\
\hline $\mathrm{Cu}^{3}$ & $\mathrm{mg} \mathrm{dm}^{-3}$ & 1.7 & 1.91 & 2.14 & 1.54 & 1.57 & 1.43 & 1.72 & 32.36 \\
\hline $\mathrm{Fe}^{3}$ & $\mathrm{mg} \mathrm{dm}^{-3}$ & 19.37 & 18.24 & 21.37 & 24.03 & 24.06 & 21.3 & 21.4 & 25.27 \\
\hline $\mathrm{Mn}^{3}$ & $\mathrm{mg} \mathrm{dm}^{-3}$ & 71.17 & 68.83 & 71.84 & 67.59 & 65.23 & 68.63 & 68.88 & 23.02 \\
\hline $\mathrm{Zn}^{3}$ & $\mathrm{mg} \mathrm{dm}^{-3}$ & $35.37 a$ & $30.80 a b$ & $32.51 a b$ & $26.61 b$ & 28.87ab & 33.47ab & 31.27 & 14.32 \\
\hline P-rem ${ }^{8}$ & $\mathrm{mg} \mathrm{L}^{-1}$ & 41.64 & 42.27 & 42.13 & 41.46 & 41.64 & 42.01 & 41.86 & 5.94 \\
\hline EC & $d S m^{-1}$ & 1.44 & 1.56 & 1.54 & 1.47 & 1.39 & 1.4 & 1.47 & 23.12 \\
\hline
\end{tabular}

${ }^{1} \mathrm{pH}$ in water; ${ }^{2}$ Colorimetry; ${ }^{3}$ Extractor: Mehlich-1; ${ }^{4}$ Extractor: $1 \mathrm{~mol} \mathrm{~L}^{-1} \mathrm{KCl} ;{ }^{5} \mathrm{pH}-\mathrm{SMP}$ method; ${ }^{6}$ Extractor: $\mathrm{BaCl}_{2} ;{ }^{7}$ Extractor: $\mathrm{Ca}\left(\mathrm{H}_{2} \mathrm{PO}\right)_{4}, 500 \mathrm{mg} \mathrm{L} \mathrm{L}^{-1}$ of $\mathrm{P}$ in 2 mol L L ${ }^{-1} \mathrm{HOAc} ;{ }^{8} \mathrm{P}$ equilibrium solution of P; SB (sum of bases); $\mathrm{t}$ (effective CEC); $\mathrm{T}$ (CEC at pH 7.0); V (base saturation); $\mathrm{m}$ (aluminum saturation); P-rem (remaining phosphorus); EC (electrical conductivity) dag/kg = $\% ; \mathrm{mg} \mathrm{dm}^{-3}=\mathrm{ppm} ; \mathrm{cmol}_{\mathrm{c}} \mathrm{dm}^{-3}=$ meq $100 \mathrm{~cm}^{-3}$. Means followed by the same letter do not differ by Tukey test at 0.05 probability level

and concentrations $\left(\mathrm{mg} \mathrm{L}^{-1}\right)$ of 3.53, 2.23, 0.15, 3.48, 5.20, 0 and 4.00 for $\mathrm{Ca}^{2+}, \mathrm{Mg}^{2+}, \mathrm{K}^{+}, \mathrm{Na}^{+}, \mathrm{Cl}^{-}, \mathrm{CO}_{3}{ }^{2-}$ and $\mathrm{HCO}_{3}{ }^{-}$, respectively.

Irrigation depths were calculated based on the reference evapotranspiration (ETo), determined daily in an automatic weather station (Vantage Pro Integrated Sensor - Davis Instruments, Wayward, CA, EUA), installed $100 \mathrm{~m}$ distant from the area, and taking into consideration efficiency of the irrigation system. Crop coefficients for the determination of ETc were defined as a function of crop phenological stages.

The treatments consisted of six banana cultivars: 'PrataAnã' (AAB) and the hybrids (AAAB) 'FHIA-01' ('Maravilha'), 'FHIA-18', 'BRS FHIA-18', 'BRS Platina' ('PA42-44') and 'JV42135 , with five replicates in a completely randomized design.

Chlorophyll indices (CI) were estimated using the Clorofilog CFL1030 chlorophyll meter (Falker'), in the third leaf from the apex, in four periods in the first and second cycles, besides a mean of five single readings for each leaf. In addition, leaf samples were collected for the determination of nutrient contents. The analysis were performed in the Laboratory of Soils of the Northern Minas Gerais Regional Unit of EPAMIG.

At the harvest of both cycles, the masses of bunches and hands $(\mathrm{kg})$ and the period from planting to harvest were evaluated for the estimation of yield, based on the equation: $t$ $\mathrm{ha}^{-1}$ year $^{-1}=\left[\right.$ production $\left(\mathrm{t} \mathrm{ha}^{-1}\right) /$ cycle duration (months) $] \mathrm{x} 12$.

After analysis of variance, the means were compared by Tukey test $(\mathrm{p}<0.05)$ and the correlations between nutrient contents and CI were estimated; those with higher magnitude and significant $(\mathrm{p}<0.05)$ were subjected to regression analysis. The selected models allowed calculating CI intervals that estimate the contents within the sufficiency range defined for 'Prata-Anã' bananas (Silva \& Borges, 2008).

CI intervals compared with field values were tested in different situations and supported the nutritional evaluation based on the estimate of leaf contents within or out of the sufficiency range established for 'Prata-Anã' bananas.

\section{Results AND Discussion}

The mean contents of nutrients in the leaves of 'Maravilha', 'BRS Platina', 'FHIA-18', 'BRS FHIA-18', 'Prata-Anã' and 'JV42135 ' showed the following decreasing order: $\mathrm{K}>\mathrm{N}>\mathrm{Ca}>\mathrm{Mg}>$ $\mathrm{S}>\mathrm{P}$ (Table 3). The contents of N, P, K and S were higher than and the contents of $\mathrm{Ca}$ and $\mathrm{Mg}$ were similar to those observed by Borges et al. (2006).

Table 3. Leaf contents of nutrients and chlorophyll of 'Prata' banana cultivars in two production cycles

\begin{tabular}{|c|c|c|c|c|c|c|c|c|c|}
\hline Characteristics & Unit & Maravilha & BRS FHIA- 18 & FHIA-18 & BRS Platina & Prata-Anã & JV42-135 & Mean & CV (\%) \\
\hline $\mathrm{N}$ & $\mathrm{g} \mathrm{kg}^{-1}$ & 30.00 & 30.50 & 30.60 & 30.29 & 30.60 & 31.70 & 31.05 & 10.20 \\
\hline P & $\mathrm{g} \mathrm{kg}^{-1}$ & 2.00 & 2.00 & 2.20 & 2.10 & 2.00 & 2.00 & 2.05 & 13.38 \\
\hline K & $\mathrm{g} \mathrm{kg}^{-1}$ & 36.80 & 38.20 & 34.70 & 40.00 & 35.30 & 37.50 & 37.08 & 7.43 \\
\hline S & $\mathrm{g} \mathrm{kg}^{-1}$ & 2.40 & 2.60 & 2.40 & 2.50 & 2.50 & 2.80 & 2.53 & 9.19 \\
\hline $\mathrm{Ca}$ & $\mathrm{g} \mathrm{kg}^{-1}$ & 7.40 & 7.90 & 10.20 & 6.60 & 8.60 & 8.00 & 8.12 & 21.75 \\
\hline $\mathrm{Mg}$ & $\mathrm{g} \mathrm{kg}^{-1}$ & 4.00 & 3.70 & 4.70 & 3.60 & 4.00 & 4.20 & 4.03 & 19.99 \\
\hline B & $\mathrm{mg} \mathrm{kg}^{-1}$ & 21.22 & 24.86 & 27.63 & 26.58 & 22.20 & 29.20 & 25.28 & 46.71 \\
\hline $\mathrm{Cu}$ & $\mathrm{mg} \mathrm{kg}^{-1}$ & 6.34 & 7.45 & 9.40 & 7.62 & 7.02 & 7.38 & 7.54 & 20.05 \\
\hline $\mathrm{Fe}$ & $\mathrm{mg} \mathrm{kg}^{-1}$ & 120.18 & 133.63 & 115.12 & 113.22 & 98.60 & 164.21 & 124.16 & 60.59 \\
\hline $\mathrm{Mn}$ & $\mathrm{mg} \mathrm{kg}^{-1}$ & 109.14 & 99.36 & 112.25 & 86.04 & 99.69 & 105.80 & 102.05 & 39.91 \\
\hline $\mathrm{Zn}$ & $\mathrm{mg} \mathrm{kg}^{-1}$ & 16.04 & 19.02 & 22.51 & 17.84 & 19.66 & 17.45 & 18.75 & 18.57 \\
\hline $\mathrm{Na}$ & $\mathrm{mg} \mathrm{kg}^{-1}$ & 36.99 & 43.39 & 29.19 & 35.50 & 40.24 & 50.85 & 39.36 & 39.43 \\
\hline Chl-a ${ }^{1}$ & - & 34.97 & 36.81 & 36.19 & 37.76 & 36.87 & 35.73 & 36.39 & 4.18 \\
\hline $\mathrm{Chl}-\mathrm{b}^{2}$ & - & 15.66 & 17.89 & 16.65 & 18.14 & 17.14 & 15.71 & 16.87 & 10.89 \\
\hline Chl-total $^{3}$ & - & 50.63 & 54.70 & 52.85 & 55.9 & 54.01 & 51.44 & 53.26 & 6.11 \\
\hline
\end{tabular}

${ }^{1}$ Chlorophyll a; ${ }^{2}$ Chlorophyll b; ${ }^{3}$ Total chlorophyll 
Nutritional status evaluations of irrigated banana orchards in Northern Minas Gerais, conducted by Silva \& Rodrigues (2001), showed the following decreasing orders of percentage of samples deficient in macronutrients: $\mathrm{K}=\mathrm{S}>\mathrm{P}>\mathrm{N}>\mathrm{Mg}>$ $\mathrm{Ca}$ and in micronutrients $\mathrm{Zn}>\mathrm{Cu}>\mathrm{Fe}>\mathrm{Mn}>\mathrm{B}$.

$\mathrm{K}$ is the nutrient absorbed in highest amounts by the plant; in addition, its high contents in the soil, in the layers of 0-20 and 21-40 cm, approximately 567.50 and $512.50 \mathrm{mg}$ $\mathrm{dm}^{-3}$ (Table 1), respectively, before planting and, on average, $297.17 \mathrm{mg} \mathrm{dm}^{-3}$ (Table 2) at the end of both cycles, contributed to its higher absorption. Differently, Borges et al. (2006) observed higher contents of $\mathrm{N}$. The low $\mathrm{K}^{+}$contents in the soil, 121.21 and $65.56 \mathrm{mg} \mathrm{dm}^{-3}$, in the layers of 0-20 and 21-40 $\mathrm{cm}$, respectively, may have influenced its lower absorption and lower leaf contents.

All the cultivars showed leaf contents of macronutrients above the sufficiency range $\left(\mathrm{g} \mathrm{kg}^{-1}\right)$ determined for 'Prata-Anã' bananas (Silva \& Borges, 2008): N (25.00-29.00); P (1.501.90); K (27.00-35.00); S (1.70-2.00); Ca (4.50-7.50) and $\mathrm{Mg}$ (2.40-4.00), except for K in 'FHIA 18' (34.70 $\left.\mathrm{g} \mathrm{kg}^{-1}\right)$ and $\mathrm{Ca}$ in 'Maravilha' (7.40 $\left.\mathrm{g} \mathrm{kg}^{-1}\right)$ and in 'BRS Platina' $\left(6.60 \mathrm{~g} \mathrm{~kg}^{-1}\right)$, which remained within the range (Table 3 ).

The leaf contents of macronutrients in the banana cultivars did not differ by Tukey test at 0.05 probability level (Table 3 ). Silva et al. (2007) also observed no difference between the leaf contents of nutrients of 99 'Prata-Anã' banana orchards, with three yield levels. These authors justified that other involved factors determined the yield. Contents above the ideal range, for all the cultivars, are related to the availability of nutrients in the soil and to the continuous translocation between the mother plant and the daughter plants, and vice versa.

The leaf contents of micronutrients in 'Prata' banana cultivars did not differ by Tukey test $(\mathrm{p}>0.05)$ (Table 3 ), which is not consistent with Borges et al. (2006), who observed differences in the contents of 24 cultivars of different subgroups.

The leaf contents of most micronutrients and sodium were within the ideal range for 'Prata-Anã', determined by Silva \& Borges (2008): B (12-25 mg kg-1); Cu (2.6-8.8 $\left.\mathrm{mg} \mathrm{kg}^{-1}\right) ; \mathrm{Fe}$ (72-157 mg kg-1); Mn (173-630 mg kg-1); Zn (14-25 mg kg$\left.{ }^{1}\right)$ and (20-60 $\left.\mathrm{mg} \mathrm{kg}^{-1}\right)$, respectively. There was a reduction of B contents in 'FHIA-18, 'BRS Platina' and 'JV42-135', Cu contents in 'FHIA-18' and Fe contents in 'JV42-135', for which the values remained above the range. Deficiency was observed for $\mathrm{Mn}$ in all the cultivars, and the values remained below the sufficiency range. The high leaf contents of micronutrients can be explained by the high contents in the soil, caused by the large supply of fertilizers characterizing the history of the area, besides irrigation.

Banana plants are usually deficient in the micronutrients $B$ and $\mathrm{Zn}$. Low leaf contents of $\mathrm{Zn}$ are common in the Northern region of Minas Gerais, associated with high $\mathrm{Zn}$ contents in the soil, which indicates restriction in its availability to plants (Rodrigues et al., 2007), probably due to the high $\mathrm{pH}$, also caused by the irrigation water.

Banana trees extract small amounts of $\mathrm{Cu}$, which is not much used in fertilization programs, due to the rare occurrence of deficiency symptoms, despite the reports of Silva \& Rodrigues (2001) for Northern Minas Gerais. Higher
$\mathrm{pH}$ conditions and large supply of organic matter reduce the availability of this nutrient.

Despite the great variation observed in leaf $\mathrm{Na}$ content (74.2\%), also reported for the Northern region of Minas Gerais (Silva \& Rodrigues, 2001), especially due to climatic conditions and irrigation water, the values obtained in the present study remained below the toxic level described in the literature.

Chlorophyll indices estimated by the device did not differ between cultivars by Tukey test ( $p>0.05$ ) (Table 3 ). Although there are differences in the efficiency of absorption of nutrients between these cultivars (Silva et al., 2014), under conditions of high fertility (Table 1), with increase in the availability of nutrients promoted by irrigation and fertilization, the high contents characterize conditions of luxury consumption, especially for $\mathrm{K}$, the element with highest cycling rate in the banana orchard.

Besides higher soil fertility, variations in crop management and climatic conditions may justify the differences in leaf contents and yields recorded in the present study (Table 4) for 'Prata-Anã, 'Maravilha' and 'BRS FHIA-18', in comparison to the results of Borges et al. (2006).

The yields observed in both cycles for the evaluated cultivars in the present study (Table 4) were high and are consistent with the results obtained by Donato et al. (2009) in similar conditions. The obtained yields, in $\mathrm{t} \mathrm{ha}^{-1}$, for mass of hands were: 37.80 and 67.80 ('BRS FHIA-18'), 32.10 and 49.90 ('FHIA-18'), 31.90 and 47.40 ('Maravilha'), 25.40 and 43.10 ('BRS Platina') and 21.30 and $34.20 \mathrm{t} \mathrm{ha}^{-1}$ ('Prata-Anã) in the first and second cycle, respectively.

The mass of hands and bunches, in both the first $(33.72 \mathrm{~kg})$ and the second $(39.40 \mathrm{~kg})$ cycle, were higher for the cultivar 'Maravilha' (Table 4). For both variables, in the first cycle, 'BRS Platina' and 'FHIA-18' showed intermediate values. 'Prata-Anã' was similar to 'BRS FHIA-18' and 'JV42-135', which did not differ from 'BRS Platina' and 'FHIA-18'. In the second cycle, 'Prata-Anã, 'BRS Platina' and 'JV42-135' showed the lowest values and 'FHIA-18' and 'BRS FHIA-18' showed intermediate values.

In the first cycle, the period from planting to harvest was 442.6 days for 'FHIA-18' and 440.7 days for 'JV42-135', a cycle longer than that of 'Maravilha' and 'BRS FHIA-18', with 385.70 and 390.66 days, respectively (Table 4); in the second cycle, the period was 670.1 days for 'Maravilha' and 513.30 days for 'BRS FHIA-18'.

For all the cultivars, the correlations were significant ( $p$ $<0.10$ ), positive and with high magnitude, between the leaf contents of at least two nutrients and the chlorophyll indices. Exceptions occurred for 'Maravilha', which showed negative associations between leaf $\mathrm{K}$ contents and chlorophyll $\mathrm{b}$ indices $(-0.88)$ and between leaf $\mathrm{Cu}$ contents and chlorophyll a indices $(-0.81)$ (Table 5). Also, for 'FHIA-18' between Ca contents and chlorophylls a and $\mathrm{b}$, as well as for $\mathrm{Cu}$ contents and chlorophyll b, and for 'JV 42-135', between leaf K contents and chlorophyll $\mathrm{b}$ and total.

Negative correlations with high magnitude between the leaf contents and chlorophyll indices were also observed in the cultivars 'JV42-135', 'FHIA-18' and 'Prata-Anã. For 'JV42-135', the negative associations occurred between leaf $\mathrm{K}$ contents 
Table 4. Agronomic characteristics of 'Prata' banana cultivars in two production cycles

\begin{tabular}{|c|c|c|c|c|c|c|c|c|c|}
\hline \multirow{2}{*}{ Characteristics } & \multirow{2}{*}{ Cycle } & \multicolumn{6}{|c|}{ Cultivars } & \multirow{2}{*}{ Mean } & \multirow{2}{*}{$\begin{array}{l}\text { CV } \\
\text { (\%) }\end{array}$} \\
\hline & & Maravilha & BRS FHIA-18 & FHIA-18 & BRS Platina & Prata-Anã & JV42-135 & & \\
\hline \multirow{2}{*}{ Mass of hands $(\mathrm{kg})$} & $1^{0}$ & $33.72 \mathrm{~A}$ & $20.86 \mathrm{BC}$ & $24.02 B$ & $21.36 \mathrm{~B}$ & $15.58 \mathrm{C}$ & $20.47 \mathrm{BC}$ & 22.67 & 12.04 \\
\hline & $2^{0}$ & $39.40 \mathrm{~A}$ & $27.34 \mathrm{~B}$ & $30.07 \mathrm{~B}$ & $21.34 \mathrm{C}$ & $19.55 \mathrm{C}$ & $19.90 \mathrm{C}$ & 26.27 & 11.1 \\
\hline \multirow{2}{*}{ Mass of bunches $(\mathrm{kg})$} & 10 & $37.9 \mathrm{~A}$ & $23.62 \mathrm{BC}$ & $27.83 \mathrm{~B}$ & $24.63 \mathrm{~B}$ & $17.99 \mathrm{C}$ & $23.29 \mathrm{BC}$ & 25.88 & 11.35 \\
\hline & $2^{0}$ & $43.4 \mathrm{~A}$ & $30.25 \mathrm{~B}$ & $34.12 \mathrm{~B}$ & $23.94 \mathrm{C}$ & $22.01 \mathrm{C}$ & $22.42 \mathrm{C}$ & 29.36 & 10.63 \\
\hline \multirow{2}{*}{ Period until harvest (days) } & $1^{0}$ & $385.70 \mathrm{~B}$ & $390.66 \mathrm{~B}$ & $442.6 \mathrm{~A}$ & $399.45 \mathrm{AB}$ & $426.00 \mathrm{AB}$ & $440.71 \mathrm{~A}$ & 414.19 & 5.4 \\
\hline & $2^{0}$ & $670.10 \mathrm{~A}$ & $513.3 \mathrm{~B}$ & $589.05 \mathrm{AB}$ & $555.08 \mathrm{AB}$ & $556.01 \mathrm{AB}$ & $612.58 \mathrm{AB}$ & 582.69 & 11.73 \\
\hline Yield in mass of hands ( $\left.\mathrm{t} \mathrm{ha}^{-1} \mathrm{year}^{-1}\right)$ & - & 52.36 & 45.06 & 44.07 & 36.92 & 30.37 & 31.62 & 40.07 & - \\
\hline Yield in mass of bunches $\left(\mathrm{t} \mathrm{ha}^{-1}\right.$ year $\left.^{-1}\right)$ & - & 58.27 & 50.40 & 50.47 & 42.00 & 34.59 & 35.81 & 45.26 & - \\
\hline
\end{tabular}

Means followed by the same letters in the row do not differ statistically by Tukey test at 0.05 probability level

Table 5. Phenotypical correlations between leaf contents of nutrients and the indices of chlorophyll $a, b$ and total, with the respective tests of significance, in 'Prata' banana cultivars

\begin{tabular}{|c|c|c|c|c|c|c|c|c|c|c|c|c|}
\hline Chlorophyll & $\bar{N}$ & $P$ & $\mathrm{~K}$ & $S$ & $\mathrm{Ca}$ & $\overline{M g}$ & B & $\mathrm{Cu}$ & $\mathrm{Fe}$ & $\overline{M n}$ & $\mathrm{Zn}$ & $\mathrm{Na}$ \\
\hline \multicolumn{13}{|c|}{ Maravilha } \\
\hline Chl-a & 0.17 & -0.02 & -0.05 & 0.73 & -0.00 & 0.08 & $0.91^{*}$ & $-0.81^{* *}$ & -0.37 & $0.85^{* *}$ & $0.92^{*}$ & 0.42 \\
\hline Chl-b & $0.96^{\star}$ & $0.81^{* *}$ & $-0.88^{* *}$ & $0.81^{\text {** }}$ & -0.46 & $0.95^{\star}$ & 0.62 & -0.14 & $0.82^{* *}$ & 0.42 & 0.19 & 0.33 \\
\hline Chl-total & $0.85^{\star \star}$ & 0.67 & -0.74 & $0.91^{\star}$ & -0.38 & $0.82^{* \star}$ & $0.81^{\star *}$ & -0.38 & $0.82^{\text {** }}$ & 0.62 & 0.45 & 0.15 \\
\hline \multicolumn{13}{|c|}{ BRS FHIA-18 } \\
\hline Chl-a & $0.98^{*}$ & 0.79 & 0.32 & $0.90^{*}$ & 0.36 & $0.82^{\star *}$ & 0.61 & 0.75 & 0.79 & 0.69 & $0.91^{\star}$ & 0.22 \\
\hline Chl-b & $0.86^{\star \star}$ & 0.39 & -0.28 & 0.60 & 0.41 & 0.61 & 0.28 & 0.57 & 0.65 & 0.62 & 0.59 & 0.24 \\
\hline Chl-total & $0.97^{\star}$ & 0.60 & -0.02 & 0.77 & 0.41 & 0.74 & 0.45 & 0.68 & 0.75 & 0.69 & 0.78 & 0.24 \\
\hline \multicolumn{13}{|c|}{ FHIA-18 } \\
\hline Chl-a & 0.50 & 0.31 & 0.18 & 0.34 & $-0.95^{*}$ & 0.70 & -0.02 & -0.24 & 0.05 & -0.24 & 0.53 & -0.10 \\
\hline Chl-b & 0.48 & 0.08 & -0.32 & 0.28 & $-0.87^{\star \star *}$ & $0.90^{\star}$ & -0.03 & $-0.87^{\star \star}$ & 0.01 & 0.14 & -0.21 & -0.63 \\
\hline Chl-total & 0.53 & 0.22 & -0.05 & 0.34 & -1.0 & $0.86^{\star \star}$ & -0.02 & -0.57 & 0.03 & -0.07 & 0.21 & -0.37 \\
\hline \multicolumn{13}{|c|}{ BRS Platina } \\
\hline Chl-a & 0.61 & 0.55 & 0.52 & 0.58 & $0.81^{\star \star}$ & 0.67 & 0.68 & 0.55 & 0.57 & 0.64 & 0.55 & 0.67 \\
\hline Chl-b & 0.74 & 0.70 & 0.71 & 0.67 & 0.65 & $0.85^{\star *}$ & 0.57 & 0.52 & 0.66 & 0.5 & 0.47 & 0.67 \\
\hline Chl-total & 0.69 & 0.64 & 0.62 & 0.63 & 0.73 & 0.77 & 0.62 & 0.53 & 0.62 & 0.618 & 0.51 & 0.67 \\
\hline \multicolumn{13}{|c|}{ Prata-Anã } \\
\hline Chl-a & $0.93^{*}$ & 0.65 & -0.08 & $0.80^{\star \star}$ & 0.62 & $0.89^{\star}$ & $0.96^{*}$ & -0.23 & 0.77 & $0.94^{*}$ & 0.69 & $-0.90^{*}$ \\
\hline Chl-b & 0.80 & $0.83^{\star \star}$ & 0.14 & 0.64 & 0.59 & 0.74 & $0.98^{\star}$ & -0.16 & 0.80 & $0.97^{*}$ & $0.84^{\star \star}$ & $-0.81^{\star *}$ \\
\hline Chl-total & $0.86^{\star \star}$ & 0.76 & 0.05 & 0.71 & 0.60 & $0.81 * *$ & $0.98^{*}$ & -0.19 & 0.80 & $0.97^{*}$ & 0.78 & $-0.86^{\star *}$ \\
\hline \multicolumn{13}{|c|}{ JV42-135 } \\
\hline Chl-a & 0.74 & 0.67 & -0.60 & -0.76 & 0.63 & $0.85^{\star \star}$ & 0.42 & -0.50 & 0.58 & 0.75 & 0.35 & 0.57 \\
\hline Chl-b & $0.82^{\star \star}$ & 0.60 & $-0.97^{\star}$ & -0.27 & $0.83^{\star \star}$ & $0.83^{* \star}$ & $0.88^{\star}$ & -0.03 & $0.83^{\star \star}$ & 1.0 & $0.86^{\star \star}$ & 0.62 \\
\hline Chl-total & $0.83^{\star \star}$ & 0.67 & $-0.86^{\star *}$ & -0.50 & 0.79 & $0.89 *$ & 0.73 & -0.24 & 0.77 & $0.95^{*}$ & 0.69 & 0.64 \\
\hline
\end{tabular}

*Significant at 0.05 probability level ** Significant at 0.10 probability level

and the indices of chlorophyll $\mathrm{b}(-0.97)$ and total (-0.86). For 'FHIA-18', negative associations occurred between leaf $\mathrm{Ca}$ contents and the indices of chlorophyll a and $\mathrm{b}(-0.95$ and -0.87 , respectively) and between leaf $\mathrm{Cu}$ contents and chlorophyll $\mathrm{b}$ (-0.87); for 'Prata-Anã, between the leaf $\mathrm{Na}$ contents and the indices of chlorophyll $\mathrm{a}, \mathrm{b}$ and total: $-0.90,-0.81$ and -0.86 , respectively (Table 5).

The leaf contents of $\mathrm{Mg}$ and $\mathrm{N}$ showed the highest number of significant, positive correlations of high magnitude with the chlorophyll indices, for all the cultivars. This is justified by the fact that both participate in the chlorophyll molecule and perform functions related to photosynthesis (Marschner, 2012).

Melo et al. (2014) also observed positive correlation between the chlorophyll content and $\mathrm{N}$ content in leaves of 'Prata-Anã' banana.

As to the micronutrients, leaf $\mathrm{B}$ content showed the highest number of significant, positive associations of high magnitude with the chlorophyll indices, because its functions are related to $\mathrm{N}$ metabolism. B deficiency reduces the use of light absorbed in the photosystems, induces the oxidation of phenolic compounds, hampers antioxidant defense mechanisms of plants and increases their susceptibility to the high intensity of light and the generation of reactive oxygen species, which would explain the direct relationship between B contents and CI (Marschner, 2012).

For 'Maravilha', the correlations with high magnitude, positive and more significant $(\mathrm{p}<0.05)$ occurred between the leaf contents of $\mathrm{N}$ and $\mathrm{Mg}$ and the index of chlorophyll $\mathrm{b}(0.96$ and 0.95 , respectively), between $S$ contents and total chlorophyll (0.91) and between the contents of B and $\mathrm{Zn}$ and the index of chlorophyll a (0.91 and 0.92, respectively) (Table 5).

For 'BRS FHIA-18', there were positive correlations, with high magnitude and significance $(\mathrm{p}<0.05)$ between leaf $\mathrm{N}$ contents and the indices of chlorophyll a (0.98) and total (0.97), between leaf S contents and chlorophyll a (0.90) and between leaf $\mathrm{Zn}$ contents and chlorophyll a (0.91) (Table 5).

For the cultivar 'FHIA-18', there was high and significant correlation at 0.05 probability level only between $\mathrm{Mg}$ contents and chlorophyll $\mathrm{b}(0.90)$, direct correlation, and between $\mathrm{Ca}$ and chlorophyll a (-0.95), inverse correlation. The high direct correlation observed between $\mathrm{Cu}$ and chlorophyll $\mathrm{b}$ was significant at 0.10 probability level; however, positive associations with high magnitude were observed for 'BRS Platina' ( $p<0.10$ ) between leaf Ca contents and the index of chlorophyll a (0.81) and between the leaf $\mathrm{Mg}$ contents and chlorophyll b (0.85) (Table 5). 
For 'Prata-Anã', direct correlations with high magnitude and significant $(\mathrm{p}<0.05)$ were observed between the leaf contents of $\mathrm{N}$ and $\mathrm{Mg}$ and the index of chlorophyll a ( 0.93 and 0.89 , respectively). The B contents in this cultivar stood out for the high degree of direct association with all the chlorophylls (a, b and total) $(0.96,0.98$ and 0.98 , respectively), as well as Mn contents and all the chlorophylls (0.94, 0.97 and 0.97 , respectively).

$\mathrm{Mn}$ is essential in the synthesis of photosynthetic pigments and acts in the activation of enzymes involved in the secondary metabolism. Its deficiency decreases the concentration of chlorophyll, drastically alters the ultrastructure of thylakoids and reduces photosynthesis and the photosynthetic evolution of $\mathrm{O}_{2}$ in the photosystem II (Marschner, 2012). Direct and significant $(\mathrm{p}<0.1)$ associations with high magnitude occurred between $\mathrm{P}$ contents and chlorophyll b (0.83), between $\mathrm{S}$ contents and chlorophyll a (0.80) and between $\mathrm{Zn}$ and chlorophyll b (0.84).

Direct, high and significant $(\mathrm{p}<0.05)$ correlations were observed for 'JV42-135' between leaf B contents and chlorophyll b (0.88); $\mathrm{Mg}$ and total chlorophyll (0.89) and between $\mathrm{Mn}$ and total chlorophyll (0.95) (Table 5). Direct, high, significant $(\mathrm{p}<0.10)$ correlations were observed between $\mathrm{N}$ and chlorophylls $\mathrm{b}$ and total ( 0.82 and 0.83 , respectively); and between $\mathrm{Ca}, \mathrm{Fe}$ and $\mathrm{Zn}$ and chlorophyll $\mathrm{b}(0.83,0.83,0.86$, respectively).

Table 6 shows the regression models and the optimal intervals of chlorophyll indices (CI), which estimate the leaf contents of nutrients within the sufficiency range determined for 'Prata-Anã', selected for all the cultivars.

For 'Maravilha', a linear model was adjusted, which estimates an increase of $1.18 \mathrm{~g} \mathrm{~kg}^{-1}$ in leaf $\mathrm{N}$ content for each unit variation in Chl-b. The model estimates leaf $\mathrm{N}$ content within the sufficiency range in the Chl-b interval of 11.44-14.81 (Table 6). The second adjusted model predicts the Mg content within the sufficiency range when the values of Chl-b are in the interval of 11.17-15.66 and predicts an increase of $0.035 \mathrm{~g}$ $\mathrm{kg}^{-1}$ of $\mathrm{Mg}$ for each unit variation in Chl-b.

Models predicting the contents of $\mathrm{B}$ and $\mathrm{Zn}$ were also adjusted for this cultivar. For B, the model predicts an increase of $12.30 \mathrm{mg} \mathrm{kg}^{-1}$ for each unit variation in $\mathrm{CI}$ and also predicts leaf $\mathrm{B}$ contents within the adequate range in the Chl-a interval of 34.05-35.27. For $\mathrm{Zn}$, the model estimates an increase of 4.48 $\mathrm{mg} \mathrm{kg}^{-1}$ for each unit variation in CI and predicts leaf contents within the sufficiency range in the Chl-a interval of 34.50-36.96.

The models selected for the prediction of $\mathrm{N}$ and $\mathrm{Zn}$ contents in 'BRS FHIA-18', based on Chl-a and total, estimate increases of $1.75 \mathrm{~g} \mathrm{~kg}^{-1}$ and $2.82 \mathrm{mg} \mathrm{kg}^{-1}$ in the leaf contents, respectively, for each unit increase in Chl-a and $0.79 \mathrm{~g} \mathrm{~kg}^{-1}$ in leaf $\mathrm{N}$ content for each unit increase in Chl-total (Table 6). The intervals of $\mathrm{Chl}-\mathrm{a}$ to predict the contents of $\mathrm{N}$ and $\mathrm{Zn}$ within the sufficiency range were 33.70-35.98 and 35.03-38.93, respectively, and the interval of Chl-total to predict leaf $\mathrm{N}$ contents within the range was 47.81-52.86.

The quadratic model adjusted for 'BRS FHIA-18' estimates the lowest leaf content of $\mathrm{Mn}, 1.05 \mathrm{mg} \mathrm{kg}^{-1}$, when Chl-total is

Table 6. Prediction equations for the leaf nutrient contents of 'Prata' banana cultivars as a function of the chlorophyll index $(\mathrm{Cl})$ generated by the Falker ${ }^{\circledR}$ Clorofilog CFL1030

\begin{tabular}{|c|c|c|c|c|}
\hline $\begin{array}{l}\text { Dependent variable } \\
\text { (leaf content) }\end{array}$ & $\begin{array}{l}\text { Independent } \\
\text { variable (CI) }\end{array}$ & Simple regression equation & $\begin{array}{c}\text { Coefficient of } \\
\text { determination }\left(R^{2}\right)\end{array}$ & $\begin{array}{l}\text { Optimal } \\
\text { Cl interval }\end{array}$ \\
\hline \multicolumn{5}{|c|}{ Maravilha } \\
\hline $\mathrm{N}$ & Chl-b & $\mathrm{N}=11.4084+1.1872 \mathrm{Chl} \mathrm{b**}$ & 0.92 & $11.44-14.81$ \\
\hline $\mathrm{Mg}$ & Chl-b & $\mathrm{Mg}=-1.59053+0.03569 \mathrm{Chl} b^{\star *}$ & 0.90 & $11.17-5.66$ \\
\hline$B$ & Chl-a & $\mathrm{B}=-408.99+12.3041 \mathrm{Chl} \mathrm{a}^{\star \star}$ & 0.82 & $34.05-5.27$ \\
\hline $\mathrm{Zn}$ & Chl-a & $\mathrm{Zn}=-140.719+4.48339 \mathrm{Chl} \mathrm{a}^{\star \star}$ & 0.84 & $34.50-36.96$ \\
\hline \multicolumn{5}{|c|}{ BRS FHIA-18 } \\
\hline $\mathrm{N}$ & Chl-a & $\mathrm{N}=-34.1489+1.75493 \mathrm{Chl} \mathrm{a}^{*}$ & 0.97 & $33.70-35.98$ \\
\hline $\mathrm{Zn}$ & Chl-a & $\mathrm{Zn}=-84.8938+2.82298 \mathrm{Chl} \mathrm{a}^{\star \star}$ & 0.84 & $35.03-38.93$ \\
\hline $\mathrm{N}$ & Chl-total & $\mathrm{N}=-12.8190+0.79102 \mathrm{Chl}^{\mathrm{T}} \mathrm{Ttal}{ }^{* *}$ & 0.94 & $47.81-52.86$ \\
\hline $\mathrm{Mn}$ & Chl-total & $\mathrm{Mn}=26971.1-1020.87 \mathrm{Chl} \mathrm{Total}^{* *}+9.66049 \mathrm{Chl} \mathrm{Total}^{* *}$ & 0.99 & $\begin{array}{l}57.05-60.71 \\
1.05(52.84)^{1}\end{array}$ \\
\hline \multicolumn{5}{|c|}{ FHIA-18 } \\
\hline K & Chl-total & $K=-116.943+5.67732 \mathrm{Chl} \mathrm{Total}^{* *}-0.05084 \mathrm{Chl}^{\text {Total }}{ }^{* *}$ & 0.99 & $\begin{array}{c}38.91-44.48 \\
41.55(55.83)^{1}\end{array}$ \\
\hline \multicolumn{5}{|c|}{ BRS Platina } \\
\hline $\mathrm{Mg}$ & Chl-b & $\mathrm{Mg}=-8.86618+0.812552 \mathrm{Chl} \mathrm{b}^{* *}$ & 0.82 & $13.86-15.83$ \\
\hline $\mathrm{Mg}$ & Chl-total & $\mathrm{Mg}=-15.3985+0.379820 \mathrm{Chl}$ Total $^{* *}$ & 0.75 & $46.86-51.07$ \\
\hline \multicolumn{5}{|c|}{ Prata-Anã } \\
\hline B & Chl-b & $B=-45.5858+3.95454 \mathrm{Chl} \mathrm{b*}$ & 0.96 & $14.05-17.84$ \\
\hline $\mathrm{Mn}$ & Chl-b & $\mathrm{Mn}=-323.451+24.6873 \mathrm{Chl} b^{* *}$ & 0.94 & $20.11-38.62$ \\
\hline $\mathrm{N}$ & Chl-total & $\mathrm{N}=-5.54102+0.669216 \mathrm{Chl}$ Total ${ }^{\star * *}$ & 0.74 & $45.63-51.61$ \\
\hline $\mathrm{Mg}$ & Chl-a & $\mathrm{Mg}=-3.00141+0.092198 \mathrm{Chl} \mathrm{a}^{\star \star}$ & 0.78 & $58.58-75.93$ \\
\hline$B$ & Chl-total & $\mathrm{B}=-104.031+2.33731 \mathrm{Chl}$ Total ${ }^{\star *}$ & 0.96 & $48.78-55.20$ \\
\hline $\mathrm{Mn}$ & Chl-total & $\mathrm{Mn}=-685.783+14.5444 \mathrm{Chl}$ Total ${ }^{\star \star}$ & 0.93 & $59.04-90.46$ \\
\hline $\mathrm{Zn}$ & Chl-total & $\mathrm{Zn}=3167.44-119.185 \mathrm{Chl}$ Total ${ }^{* *}+1.12603 \mathrm{Chl}$ Total $2 * \star$ & 0.99 & $\begin{array}{c}53.48-56.09 \\
13.65(52.92)^{1}\end{array}$ \\
\hline \multicolumn{5}{|c|}{ JV42-135 } \\
\hline $\mathrm{Mg}$ & Chl-total & $\mathrm{Mg}=-15.5538+0.3840055 \mathrm{Chl}$ Total ${ }^{* *}$ & 0.79 & $47.24-51.45$ \\
\hline $\mathrm{Mn}$ & Chl-total & $\mathrm{Mn}=-1070.17+22.8633 \mathrm{Chl}$ Total ${ }^{* *}$ & 0.90 & $54.37-74.36$ \\
\hline
\end{tabular}

for the quadratic models and the correspondent $\mathrm{Cl}$ 
equal to 52.84 and the leaf contents within the sufficiency range for the Chl-total interval of 57.05-60.71.

For 'FHIA-18', the model predicts the highest $\mathrm{K}$ content $\left(41.55 \mathrm{~g} \mathrm{~kg}^{-1}\right)$ for Chl-total of 55.83 and contents within the sufficiency range in the interval of 38.91-44.48.

The models adjusted for 'BRS Platina' estimated $\mathrm{Mg}$ contents within the sufficiency range as a function of Chl-b and total, in the intervals of 13.86-15.83 and 46.96-51.07, respectively (Table 6). The models estimated increases of 0.81 $\mathrm{g} \mathrm{kg}^{-1}$ and $0.38 \mathrm{mg} \mathrm{kg}^{-1}$ of $\mathrm{Mg}$ for each unit variation in Chl-b and Chl-total, respectively.

The models selected for 'Prata-Anã' considered the nutrients that commonly cause deficiency symptoms at the field. Linear models were selected as a function of Chlorophyll b, which estimate the leaf contents of $\mathrm{B}$ and $\mathrm{Mn}$ within the sufficiency range, in the Chl-b intervals of 14.05-17.84 and 20.11-38.62, respectively (Table 6). The models predict increases of 3.95 $\mathrm{mg} \mathrm{kg}^{-1}$ and $24.68 \mathrm{mg} \mathrm{kg}^{-1}$ for B and $\mathrm{Mn}$, respectively, for each unit variation in Chl-b.

Models related to total chlorophyll were also selected, which predict the leaf contents of N, B and Mn within the sufficiency range, in Chl-total intervals of 45.63-51.61, 48.78-55.20 and 59.04-90.46, respectively, which estimate increases of $0.67 \mathrm{~g} \mathrm{~kg}^{-1}$, $2.34 \mathrm{mg} \mathrm{kg}^{-1}$ and $14.54 \mathrm{mg} \mathrm{kg}^{-1}$, for N, B and Mn respectively, for each unit variation in Chl-total. The quadratic model, as a function of Total chlorophyll, predicts the highest leaf content of $\mathrm{Zn}, 13.65 \mathrm{~g} \mathrm{~kg}^{-1}$, for Chl-total of 52.92, and leaf contents within the sufficiency range in the interval of 53.48-56.09.

Estimates of leaf Mg contents for the cultivar 'Prata-Anã' were performed using the model adjusted as a function of Chl-a, which predicts an increment of $0.092 \mathrm{~g} \mathrm{~kg}^{-1}$, for each unit increase in Chl-a. The mathematical model estimates the content of $\mathrm{Mg}$ within the sufficiency range in the Chl-a interval of 58.58-75.93.

A model that estimates leaf $P$ contents was also adjusted for 'Prata-Anã'. P is the third nutrient that most causes deficiency symptoms at the field, although with low application response (Silva \& Rodrigues, 2013). The model based on the indices of chlorophyll $\mathrm{a}$ and $\mathrm{b}(\mathrm{P}=0.9975458+0.038125 \mathrm{Chl} \mathrm{b}+$ $0.039292 \mathrm{Chl}$ a) was not shown in Table 6, because it demands calculations for obtaining $\mathrm{P}$ contents, which makes its use difficult, but does not invalidate it.

For 'JV42-135', the models estimate the contents of $\mathrm{Mg}$ and $\mathrm{Mn}$ within the optimal range, as a function of Chl-total in the intervals of 47.24-51.45 and 54.37-74.36, respectively, and also estimate increases of $0.38 \mathrm{~g} \mathrm{~kg}^{-1}$ and $22.86 \mathrm{mg} \mathrm{kg}^{-1}$ in the leaf contents of $\mathrm{Mg}$ and $\mathrm{Mn}$, respectively, for each unit variation in Chl-total.

The optimal CI intervals determined through regression models can serve as a basis for the inference on the nutritional status of banana orchards in real time, in a practical, fast and inexpensive way. The technique requires no calculation and consists in the comparison between the values obtained with the device and the intervals (Table 6).

\section{Conclusions}

1. The adjusted models are able to provide a real-time, reliable prediction of the nutritional status of 'Prata' bananas, in an easy, fast and inexpensive way.
2. The prediction of banana nutritional status based on mathematical models is an important auxiliary tool that, combined with leaf and soil analyses, contributes to a more precise and secure evaluation.

\section{Literature Cited}

Backes, C.; Bôas, R. L. V.; Lima, C. P.; Godoy, L. J. G.; Büll, L. T.; Santos, A. J. M. Estado nutricional em nitrogênio da grama esmeralda avaliado por meio do teor foliar, clorofilômetro e imagem digital, em área adubada com lodo de esgoto. Bragantia, v.69, p.661-668, 2010. http://dx.doi.org/10.1590/S0006-87052010000300018

Borges, A. L.; Silva, S. O.; Caldas, R. C.; Ledo, C. A. S. Teores foliares de nutrientes em genótipos de bananeira. Revista Brasileira de Fruticultura, v.28, p.314-318, 2006. http://dx.doi.org/10.1590/ S0100-29452006000200036

Donato, S. L. R.; Arantes, A. M.; Silva, S. O.; Cordeiro, Z. J. M. Comportamento fitotécnico da bananeira 'Prata-Anã' e de seus híbridos. Pesquisa Agropecuária Brasileira, v.44, p.1508-1515, 2009. http://dx.doi.org/10.1590/S0100-204X2009001200007

Donato, S. L. R.; Lédo, A. A.; Pereira, M. C. T.; Coelho, E. F.; Cotrim, C. E. Estado nutricional de bananeiras tipo prata sob diferentes sistemas de irrigação. Pesquisa Agropecuária Brasileira, v.45, p.980-988, 2010. http://dx.doi.org/10.1590/S0100204X2010000900007

Fontes, P. C. R. Nutrição mineral de plantas: Adubação e diagnose. Viçosa: Fontes, P. C. R., 2011, 269p.

Godoy, L. J. G.; Santos, T. S.; Villas-Bôas, R. L.; Leite Júnior, J. B. Índice relativo de clorofila e o estado nutricional em nitrogênio durante o ciclo do cafeeiro fertirrigado. Revista Brasileira de Ciência do Solo, v.32, p.217-226, 2008. http://dx.doi.org/10.1590/ S0100-06832008000100021

Haim, P. G.; Zoffoli, B. C.; Zonta, E.; Araújo, A. P. Diagnose nutricional de nitrogênio em folhas de feijoeiro pela análise digital de imagens. Pesquisa Agropecuária Brasileira, v.47, p.1546-1549, 2012. http://dx.doi.org/10.1590/S0100-204X2012001000019

Marschner, P. Marschner's mineral nutrition of higher plants. 3.ed. London: Elsevier, 2012. 651p.

Melo, A. S. de; Silva Júnior, C. D.; Fernandes, P. D.; Brito, M. E. B.; Sobral, L. F.; Suassuna, J. F.; Viégas, P. R. A.; Ferraz, R. L. S. Chlorophyll and macronutrients content in leaf tissue of Musa sp. 'Prata-Anã' under fertigation. African Journal of Agricultural Research, v.9, p.1714-1720, 2014. http://dx.doi.org/10.5897/ AJAR2014.8683

Nomura, E. S.; Teixeira, L. A. J.; Boaretto, R. M.; Garcia, V. A.; Fuzitani, E. J.; Damatto Júnior, E. R.; Saes, L. A.; Mattos Júnior, D. Aplicação de boro em bananeira. Revista Brasileira de Fruticultura, v.33, p.608-617, 2011. http://dx.doi.org/10.1590/ S0100-29452011000200034

Pôrto, M. L.; Puiatti, M.; Fontes, P. C. R.; Cecon, P. R.; Alves, J. C.; Arruda, J. A. Índice SPAD para o diagnóstico do estado de nitrogênio na cultura da abobrinha. Horticultura Brasileira, v.29, p.311-315, 2011. http://dx.doi.org/10.1590/S010205362011000300009

Reis, A. R.; Furlani Júnior, E.; Buzetti, S.; Andreotti, M. Diagnóstico da exigência em nitrogênio pela utilização do medidor portátil de clorofila. Bragantia, v.65, p.163-171, 2006. http://dx.doi. org/10.1590/S0006-87052006000100021 
Ribeiro, H. M.; Vasconcelos, E.; Ramos, A.; Coutinho, J. Avaliação do estado nutricional azotado de pés-mãe de Eucalyptus globulus Labill. ssp. globulus com recurso a um medidor portátil de clorofila. Revista de Ciências Agrárias, v.32, p.4049, 2009.

Rodrigues, M. G. V.; Dias, M. S. C.; Ruggiero, C.; Lichtemberg, L. A. Planejamento, implantação e manejo do bananal. In: Informe Agropecuário, v.29, p.14-22, 2008.

Rodrigues, M. G. V.; Ruggiero, C.; Natale, W.; Pacheco, D. D. Nutrição e produção da bananeira 'Prata-Anã' adubada com zinco e boro diretamente no rizoma, via muda desbastada. Revista Brasileira de Fruticultura, v.29, p.645-651, 2007. http://dx.doi.org/10.1590/ S0100-29452007000300042

Silva, E. B.; Rodrigues, M. G. V. Levantamento nutricional dos bananais da região norte de Minas Gerais pela análise foliar. Revista Brasileira de Fruticultura, v.23, p.695-698, 2001. http:// dx.doi.org/10.1590/S0100-29452001000300050
Silva, E. B.; Souza, B. P.; Donato, S. L. R.; Amorim, E. P.; Carvalho, F. P.; Almeida, M. O. Deficiências de macronutrientes no estado nutricional de mudas de bananeira tipo Prata. Bioscience Journal, v.30, p.82-92, 2014.

Silva, J. T. A.; Borges, A. L. Solo, nutrição mineral e adubação da bananeira. Informe Agropecuário, v.29, p.25-37, 2008.

Silva, J. T. A.; Pacheco, D. D.; Costa, E. L. Atributos químicos e físicos de solos cultivados com Bananeira 'Prata-Anã' ( $\mathrm{AAB}$ ), em três níveis de produtividade, no Norte de Minas Gerais. Revista Brasileira de Fruticultura, v.29, p.102-106, 2007. http://dx.doi. org/10.1590/S0100-29452007000100022

Silva, J. T. A.; Rodrigues, M. G. V. Produção da bananeira 'Prata-Anã' em função da aplicação de adubo fosfatado, em quatro ciclos. Pesquisa Agropecuária Brasileira, v.48, p.613-618, 2013. http:// dx.doi.org/10.1590/S0100-204X2013000600006

Swiader, J. M.; Moore, A. SPAD-Chlorophyll response to nitrogen fertilization and evaluation of nitrogen status in dryland and irrigated pumpkins. Jounal of Plant Nutrition, v.25, p.1089-1100, 2002. http://dx.doi.org/10.1081/PLN-120003941 